\title{
Does extra feeding of cows during winter and early spring pay?
}

\author{
J.D. MORTON' and D.P. JENSEN ${ }^{2}$ \\ 'MAF Technology, Canterbury Agricultural and Science Centre, \\ P.O. Box 24, Lincoln, Canterbury, New Zealand \\ ${ }^{2}$ N.Z. Dairy Board, Christchurch
}

\begin{abstract}
The effect of winter and spring feeding on milk production was investigated on a MidCanterbury dairy farm. High feeding of Friesian/Jersey cows to gain $64 \mathrm{~kg}$ of liveweight during winter resulted in an extra $20 \mathrm{~kg}$ of milkfat and $15 \mathrm{~kg}$ of milk protein production compared with feeding to maintain empty body liveweight. Extra feeding of cows during the first 8 weeks of lactation produced $7 \mathrm{~kg}$ of milkfat and $6 \mathrm{~kg}$ of milk protein over that period. The carry-over effect from this for the next 22 weeks of lactation of normal feeding was an extra $11 \mathrm{~kg}$ of milkfat and $5 \mathrm{~kg}$ of milk protein per cow. Simple financial analysis showed that off-farm wintering of cows to either maintain or gain liveweight and consequent high spring feeding were profitable options returning \$40-42 per cow after extra grazing and topping costs.
\end{abstract}

K eywords winter, spring, feeding, milkfat,-milk. protein, production

\section{Introduction}

Seasonal dairy farming in Canterbury has expanded rapidly since 1980 owing to various environmental and economic advantages, one of which is the availability of relatively low cost winter feed grown on surrounding arable farms. These feeds include greenfeed oats, rape, turnips, dryland pasture of low to medium quality and barley and grass seed stubble and straw. Their availability enables dairy herds to be grazed off-farm. During winter the cows can be either fed to maintain or gain condition, depending on feed allowance and the nutritive value of the offered feed. Off-farm wintering increases farm pasture cover at calving which provides the opportunity to offer the herd more pasture in early lactation. This paper outlines a trial that investigated the effects of high winter and spring feeding on milk production and discusses the financial implications of these management changes.

\section{Materials and methods}

The trial was conducted on a commercial dairy farm at Dromore near Ashburton in Mid Canterbury. On 22 May 1989, 80 early-calving Friesian/Jersey cows (mean liveweight $402 \mathrm{~kg}$, mean condition score (CS) 4.8 with a mean breeding index (BI) of 117 ) were selected and separated into two winter grazing treatment groups that were balanced for cow age and BI. During winter (22 May to 14 August), the normal feeding treatment group was offered a mean daily pasture allowance of $8 \mathrm{~kg} \mathrm{DM} / \mathrm{cow}$ and the high feeding treatment group $16 \mathrm{~kg} \mathrm{DM} / \mathrm{cow}$. Each treatment group was shifted daily on pastures with an average 50\% ryegrass, 20\% clover content, and dry matter digestibility (DMD) of 78\%.

During calving (14-29 August), all cows were grazed together and fed to requirements in precalving and colostrum groups. From 29 August to 24 October, the 80 lactating cows from the winter feeding treatment were randomly allocated into two spring feeding treatment groups, so that each group consisted of 20 cows from the normal winter feeding group and 20 cows from the high winter feeding -group. The. 40 cows in the normal spring feeding group were offered a mean daily pasture allowance of $27 \mathrm{~kg} \mathrm{DM} /$ cow and the 40 cows in the high spring feeding group $54 \mathrm{~kg} \mathrm{DM} /$ cow. The two groups were shifted daily after the morning milking, on pastures $(\mathrm{DMD}=84 \%)$ containing on average $70 \%$ ryegrass and $10 \%$ clover and were grazed in two 28-day rotations over the same paddocks at a mean stocking rate of 2.7 cows/ha,

From the end of the treatment period (24 October 1989) to 28 March 1990. the trial cows were grazed in equal numbers in two herds and offered a similar normal pasture allowance.

Pre- and post-grazing pasture dry matter (DM) mass was measured weekly for each treatment group by visual assessment and correction regression from five $0.25 \mathrm{~m}^{2}$ quadrats cut to ground level. Cow liveweight and CS were assessed at the start (22 May), pre-calving (14 August) and end (24 October) of the trial. Gut fill was estimated from pasture intake and time of weighing in relation to grazing so that empty body liveweight could be derived.

Milkfat and protein production were measured from each cow three times weekly during September 
Table 1 Effect of winter and spring feeding on change in cow liveweight $(\mathrm{kg})$ and condition score

\begin{tabular}{lcccc}
\hline Feeding treatment & $\begin{array}{c}\text { Change in } \\
\text { liveweight }\end{array}$ & $\begin{array}{c}\text { Winter } \\
\text { Change in } \\
\text { condition } \\
\text { score }\end{array}$ & $\begin{array}{c}\text { Change in } \\
\text { liveweight }\end{array}$ & $\begin{array}{c}\text { Spring } \\
\text { Change in } \\
\text { condition } \\
\text { sc 0 re }\end{array}$ \\
\hline Normal winter & +27 & $+\mathbf{0 . 1}$ & -22 & -0.4 \\
High winter & +91 & +1.3 & -85 & -1.2 \\
Normal spring & & & -74 & -1.0 \\
High spring & 6.9 & 0.17 & -33 & -0.7 \\
LSD (5\%) & & & 10.1 & 0.19 \\
\hline
\end{tabular}

and twice weekly during October. Monthly Livestock Improvement Corporation herd testing data was used for milkfat and milk protein measurements from the end of the trial to 28 March 1990.

\section{Statistical analysis}

The data for milkfat and milk protein production were subjected to analysis of variance according to a $2 \times 2$ factorial design.

\section{Results and Discussion}

\section{Pasture intake}

During winter the cows were offered a pre-grazing pasture mass of $3300 \mathrm{~kg} \mathrm{DM} / \mathrm{ha}$ and grazed to postgrazing pasture masses of 670 and $1150 \mathrm{~kg} \mathrm{DM} / \mathrm{ha}$ for the normal and high winter feeding group respectively. In spring the pre-grazing pasture mass increased to $3840 \mathrm{~kg} \mathrm{DM} / \mathrm{ha}$ and the post-grazing pasture mass to 1260 and $1970 \mathrm{~kg} \mathrm{DM} /$ ha for the normal and high feeding groups respectively.

Mean apparent pasture daily intakes were 7 and 13 $\mathrm{kg} \mathrm{DM} /$ cow for normal and high winter feeding treatments and 17 and $25 \mathrm{~kg} \mathrm{DM} /$ cow for normal and high spring feeding treatments, respectively. Research data reported by Holmes (1987) indicate that actual daily intakes from the allowances offered are more likely to be 6 and $10 \mathrm{~kg} \mathrm{DM} / \mathrm{cow}$ for normal and high winter feeding treatments and 13 and $17 \mathrm{~kg}$ $\mathrm{DM} /$ cow for normal and high spring feeding treatments respectively. The overestimation of intake was probably due to pasture being trampled into the soil during grazing and not recovered in the postgrazing pasture mass measurements. This effect would be expected to increase at high pasture intake and post-grazing pasture mass, because a greater amount of pasture would be susceptible to trampling.

\section{Cow liveweight and condition score}

Changes in cow conditon score corresponded to changes in liveweight during winter and early spring (Table 1).

The changes in cow liveweight and CS during winter reflect the pasture intake of the treatment groups. As reported by Grainger \&McGowan (1982). the heavier cows at calving lost more liveweight in early lactation than lighter cows and a higher level of feeding in early lactation resulted in a lower loss of cow liveweight and condition, as found by Grainger et al. (1982).
The difference in apparent daily intake between normal and high winter feeding treatments over an 84-day period showed that an extra $523 \mathrm{~kg}$ of DM was required to increase liveweight at calving by 64 $\mathrm{kg}$, which is in line with relationships found by Grainger et al. (1982).

\section{Milkfat and protein production}

The increase in milkfat production $(20 \mathrm{~kg} / \mathrm{cow}$, Table 2) up to the end of March from the extra $64 \mathrm{~kg}$ liveweight at calving due to high winter feeding, was similar to that measured by other workers. Research results reviewed by Grainger \& McGowan (1982) showed a benefit of about $1 \mathrm{~kg}$ of milkfat per $4 \mathrm{~kg}$ liveweight increase at calving; nearly half of this increase was gained in the first 8 weeks of lactation.

The increase in milkfat production from high spring feeding during the first 8 weeks after calving (7 $\mathrm{kg} / \mathrm{cow}$, Table 2) was similar to the winter feeding effect. There was a carry-over effect of $11 \mathrm{~kg}$ of milkfat per cow during the 22 weeks of lactation after the period of extra feeding. From data presented by Bryant \& Trigg (1972), the response in milkfat production to an extra $1 \mathrm{~kg}$ of pasture DM consumed was estimated to be $39 \mathrm{~g}$ as an immediate effect and $49 \mathrm{~g}$ as a carry-over effect. Using these conversions, the apparent extra $7 \mathrm{~kg} \mathrm{DM} / \mathrm{cow}$ consumed at the high spring feeding treatment would have been expected to yield an extra $14 \mathrm{~kg}$ of milkfat per cow during early lactation and an extra $18 \mathrm{~kg}$ of milkfat per cow in the remainder of the lactation. The actual increase in milkfat production of 7 and $11 \mathrm{~kg}$ milkfat for each period suggests that the real difference in pasture intake was 3-4 $\mathrm{kg}$ of DM per cow during early lactation, as suggested by Holmes (1987).

The combined winter and spring feeding treatments showed that both normal winter-high spring and high winter-normal spring feeding produced similar increases in milkfat production (6-8 $\mathrm{kg}$ of milkfat per cow in the first 8 weeks; $27-29 \mathrm{~kg}$ of milkfat per cow in the first 30 weeks) compared with normal winter-normal spring feeding. The high winter-high spring feeding produced an extra $16 \mathrm{~kg}$ of milkfat per cow in the first 8 weeks compared with the normal winter-normal spring feeding treatment. This increased to an extra $39 \mathrm{~kg}$ of milkfat per cow over the first 30 weeks of lactation.

For all treatment effects, milk protein producton gave similar percentage responses to milkfat 
Table 2 Effect of winter and spring feeding on milkfat and milk protein production (kg/cow).

\begin{tabular}{|c|c|c|c|c|c|}
\hline \multirow{2}{*}{\multicolumn{2}{|c|}{ Feeding treatment }} & \multicolumn{2}{|c|}{ Milkfat production } & \multicolumn{2}{|c|}{ Milk protein production } \\
\hline & & $\begin{array}{l}29 \text { August } \\
24 \text { October }\end{array}$ & $\begin{array}{c}29 \text { August . } \\
28 \text { March }\end{array}$ & $\begin{array}{l}29 \text { August } \\
24 \text { October }\end{array}$ & $\begin{array}{c}29 \text { August } \\
28 \text { March }\end{array}$ \\
\hline \multirow{2}{*}{\multicolumn{2}{|c|}{$\begin{array}{l}\text { Normal winter } \\
\text { High Winter }\end{array}$}} & 49 & 171 & 41 & 127 \\
\hline & & 58 & 191 & 45 & 142 \\
\hline \multirow{2}{*}{\multicolumn{2}{|c|}{$\begin{array}{l}\text { Normal Spring } \\
\text { High Spring }\end{array}$}} & 50 & 172 & 40 & 129 \\
\hline & & 57 & 190 & 46 & 140 \\
\hline \multicolumn{2}{|c|}{ LSD $(5 \%)$} & 2.3 & 13.8 & 2.3 & 10.2 \\
\hline Winter & Spring & & & & \\
\hline Normal & Normal & 46 & 157 & 38 & 118 \\
\hline Normal & High & 52 & 184 & 44 & 135 \\
\hline High & Normal & 54 & 186 & 42 & 139 \\
\hline High & High & 62 & 196 & 48 & 145 \\
\hline LSD & & 3.6 & 19.5 & 3.1 & 14.4 \\
\hline
\end{tabular}

production over the first 30 weeks of lactation, as also reported by Holmes (1989).

\section{Financial implications of extra winter} and spring feeding

Extra spring feeding can only be economically provided by increasing pasture cover at calving through off-farm winter grazing. The winter and spring feeding effects on milkfat production from the trial can be used to estimate the net return from different off-farm winter feeding levels and subsequent spring feeding levels (Table 3). Winter pasture growth rates for dairy pastures in Mid Canterbury (10-15 kg DM/ha/day) are sufficient to provide the high spring pasture allowances used in the trial if the pasture is left ungrazed during winter. In the trial, the high spring feeding group had twice the area of pasture offered at the same pre-grazing -pasture mâss compared with the normal spring feeding group and hence were at a lower stocking rate. The following financial analysis assumes that a higher pre-grazing pasture mass is offered to allow higher spring feeding compared with normal spring feeding over the same area, so that stocking rate per se is identical for each strategy.

The financial analysis is carried out assuming a $\$ 4$ return $/ \mathrm{kg}$ of milkfat at a cost of $10 \mathrm{c} / \mathrm{kg}$ DM for offfarm grazing over an 84-day winter at the measured daily pasture intakes and a cost of $\$ 20 /$ ha for topping surplus pasture in the spring. Most of the off-farm winter grazing in Mid Canterbury is on greenfeed oats on which measurements (Morton, unpublished data) have shown that high feed intakes can be acheived at a low post-grazing feed mass. Hence the per $\mathrm{kg}$ DM grazing cost used is the same for both normal and high winter feeding.

The high winter-normal spring feeding strategy would occur if on-farm winter or spring pasture growth rates were below average. Although this strategy resulted in a breakeven situation, the offfarm winter grazing would still provide sufficient pasture at calving to prevent severe under feeding of cows and subsequent losses in milk production during early laction that would otherwise have occurred. There is little difference in profit from the other two strategies. The extra milk production from high winter feeding was counterbalanced by the cost of extra winter grazing in the high winter-high spring feeding strategy. This strategy could also carry more risk, since the off-farm feed source would have to be of sufficient-quality-to-increase-condition.

In the analysis the other benefits from extra winter and spring feeding have not been included, These include improved reproductive performance from cows in better condition at the start of mating, which will contribute to the next season's production and reduce animal health costs. There is also an opportunity for milk production per cow to be increased by lengthening the lactation through calving earlier or drying off later. Off-farm wintering also enables the cost of making supplement to be reduced and provides the opportunity to use late spring surplus -pasture to milk extra cows. An increase in stocking rate would probably be a more profitable option than using the extra pasture to increase milk production per cow.

Table 3 Financial analysis $(\$ / \mathrm{cow})$ of different winter and spring feeding strategies compared with normal management.

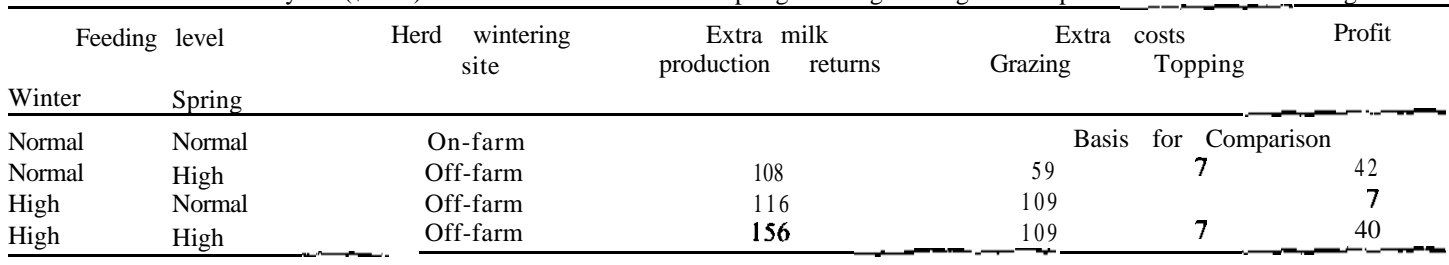




\section{Conclusions}

1. Feeding cows twice maintenance over winter and increasing liveweight by $64 \mathrm{~kg}$ at calving resulted in a large increase in milkfat ( $20 \mathrm{~kg} / \mathrm{cow})$ and protein $(15 \mathrm{~kg} / \mathrm{cow})$ production in the following lactation.

2. High compared with normal feeding during the first 8 weeks of lactation increased milkfat production by $7 \mathrm{~kg} / \mathrm{cow}$ and milk protein production by $6 \mathrm{~kg} / \mathrm{cow}$ over that period.

3. The carry-over effect from higher spring feeding during the next 22 weeks was an extra $11 \mathrm{~kg}$ of milkfat and $5 \mathrm{~kg}$ of milk protein per cow.

4. Financial analysis of combinations of winter and spring feeding showed that wintering off-farm and feeding at normal or high levels, which then allowed high spring feeding, returned a profit of $\$ 40-42$ per cow.

\section{ACKNOWLEDGEMENTS}

The authors wish to thank John and Lois Roadley and their farm staff for their kind assistance in providing resources and carrying out the extra work involved. Our thanks also to the Winchmore Research Station staff; Robin Burton for technical assistance and farm staff for setting up fences and water.

\section{REFERENCES}

Bryant, A.M.; Trigg, T.E. 1979. Immediate and longer term response of dairy cows to level of nutrition in early lactation. Proceedings of fhe $N Z$ Society of Animal Production 39: 139-I 47.

Holmes, C.W. 1987. Pasture for dairy cattle. In: Nicol A.M.(Ed.) Livestock feeding on pasture.- NZ Society of Animal Production O ccasional Publication No. 10. Holmes, C.W. 1989. Effects of feeding on the composition of milk and on the yield of its components. Proceedings Lincoln College Seminar on Milk Q ualify: 43-53.

Grainger, C.; McGowan, A.A. 1982. The significance of pre-calving nutrition of the dairy cow. Proceedings of the Conference on Dairy Production from Pasture: 135-171.

Grainger, C.; Wilhelms, D.; McGowan, A.A. 1982. Effect of body condition at calving and level of feeding in early lactation on milk production of dairy cows. Australian journal of experimental agriculture and animal husbandry 22: $9-17$. 